\title{
Phthalocyanine-modified silica gels and their application in the purification of unsymmetrical phthalocyanines
}

\author{
Clifford C. Leznoff, ${ }^{1}$ Colin R. Mcarthur, and Yongnian Qin \\ Department of Chemistry, York University, North York (Toronto), ON M3J IP3, Canada
}

\begin{abstract}
Clifford C. Leznoff, Colin R. McArthur, and Yongnian Qin. Can. J. Chem. 71, 1319 (1993).
Five species of phthalocyanine-modified silica gels were prepared. The loadings of phthalocyanine on these silica gels were determined by acidic hydrolysis. The concept of using the aggregation phenomenon to advantage to aid chromatographic separation of unsymmetrical phthalocyanines was investigated by employing these modified silica gels as chromatographic media to purify unsymmetrical phthalocyanines. Four groups of phthalocyanine mixtures were prepared by mixed condensation. One of the desired unsymmetrical phthalocyanines was successfully purified by conventional column chromatography while others were separated by the new method described herein.
\end{abstract}

Clifford C. Leznoff, Colin R. McArthur et Yongnian Qin. Can. J. Chem. 71, 1319 (1993).

On a préparé cinq espèces de gels de silice modifiés par des phtalocyanines. On a déterminé la quantité de phtalocyanine présente sur ces gels de silice en faisant appel à une hydrolyse acide. On a étudié le concept de l'utilisation du phénomène d'agrégation pour faciliter la séparation chromatographique de phtalocyanines non symétriques en utilisant ces gels de silice modifiés comme milieux chromatographiques pour la purification de phtalocyanines non symétriques. On a préparé quatre groupes de mélanges de phtalocyanines par condensations mixtes. On a réussi à purifier une des phtalocyanines non symétriques désirées par chromatographie conventionnelle sur colonne alors que les autres ont été séparées par la méthode décrite ici.

[Traduit par la rédaction]

Unsymmetrical phthalocyanines present challenges in the development of new methods of synthesis and separation. The potential use of phthalocyanines for photodynamic therapy (PDT) of cancer has sparked considerable interest in the photobiology of these compounds (1-9). To find a suitable phthalocyanine as photosensitizer, it is necessary to tune the position of its absorption band. Such fine tuning can be achieved by the stepwise introduction of peripheral substituent groups or by the stepwise adjustment of the size of the $\pi$-conjugated macrocyclic systems (10-13). Thus, unsymmetrical phthalocyanines are important goals in synthesis. Although symmetrical tetra- and octasubstituted phthalocyanines are well known, the synthesis of simple mono- and disubstituted and other unsymmetrical phthalocyanines remains a difficult problem (10-21). For instance, all tetrasubstituted phthalocyanines so far synthesized contain one substituent in each of the benzene rings, and no phthalocyanines such as $1,2,3,4$ - or 1,2,3,8-tetrasubstituted phthalocyanines have been reported.

Successful methods for the synthesis of unsymmetrical phthalocyanines can be divided into three groups according to strategy: (1) the polymer support route $(14,16,19,20)$; (2) the homogeneous mixed condensation route $(12-14,21)$; and (3) the subphthalocyanine route (11). There are difficulties with all three routes for large-scale preparation of unsymmetrical alkoxy-substituted phthalocyanines.

Route $\mathrm{l}$ is not suitable for large-scale preparation of unsymmetrical phthalocyanines. Route 3 is not suitable for the preparation of alkoxy-substituted phthalocyanines, as this method uses $\mathrm{BBr}_{3}$, an ether-cleaving reagent. Route 2 , the ordinary method of forming unsymmetrical phthalocyanines by mixed condensation of different phthalonitriles, most often gives statistical mixtures of phthalocyanines, which are very difficult to separate by common chromatographic methods. Although purifications of desired unsymmetrical phthalocyanines from mixed condensations by

'Author to whom correspondence may be addressed. common chromatographic methods have been reported, success has been achieved only with those phthalocyanines having greatly differing polarities and after numerous repetitions of chromatographic separations. There appear to be two reasons for such difficulties. First, a number of very similar phthalocyanine species exist in the mixture. With siteisomers considered, a mixture from a mixed condensation conceivably can contain more than 20 species of similar phthalocyanines! Second, strong aggregation (22-24) exists among the different phthalocyanine species. Generally speaking, one of the basic premises and presumptions of chromatography is that each gradient to be separated should behave independently without interfering with another. The premise is not valid if aggregation occurs. Thus, a well-defined band on column chromatography or a single spot on thin-layer chromatography (TLC) is by itself insufficient evidence of purity and should be accompanied by mass spectral and other spectroscopic data (15).

In this investigation, the homogeneous mixed condensation route was used, together with work aimed at developing a more powerful method of separation. For the latter, we envisioned and investigated a new strategy which takes advantage of the aggregation that would be expected to occur between immobilized phthalocyanines and those in the synthetic mixture.

Five species of phthalocyanine-modified silica gels (Pc-SiGels) were prepared. These Pc-Si-Gels can be divided into three groups. In the first group, flash grade silica gel (1), preactivated with concentrated hydrochloric acid (25), reacted with thionyl chloride to give chlorinated silica gel (2). A reaction between 2 and 2,9,16,23-tetrakis(2-hydroxymethyl-2-methylbutoxy)phthalocyanine (3) (14) gave a modified silica gel (4), which contained phthalocyanine entities bonded to silica through $\mathrm{Si}-\mathrm{O}-\mathrm{C}$ linkages (Scheme 1). It should be noted that the phthalocyanine entities could be bonded to silica through more than one $\mathrm{Si}-\mathrm{O}-\mathrm{C}$ linkage (26), so its structure shown in Scheme 1 represents a simplified model. 

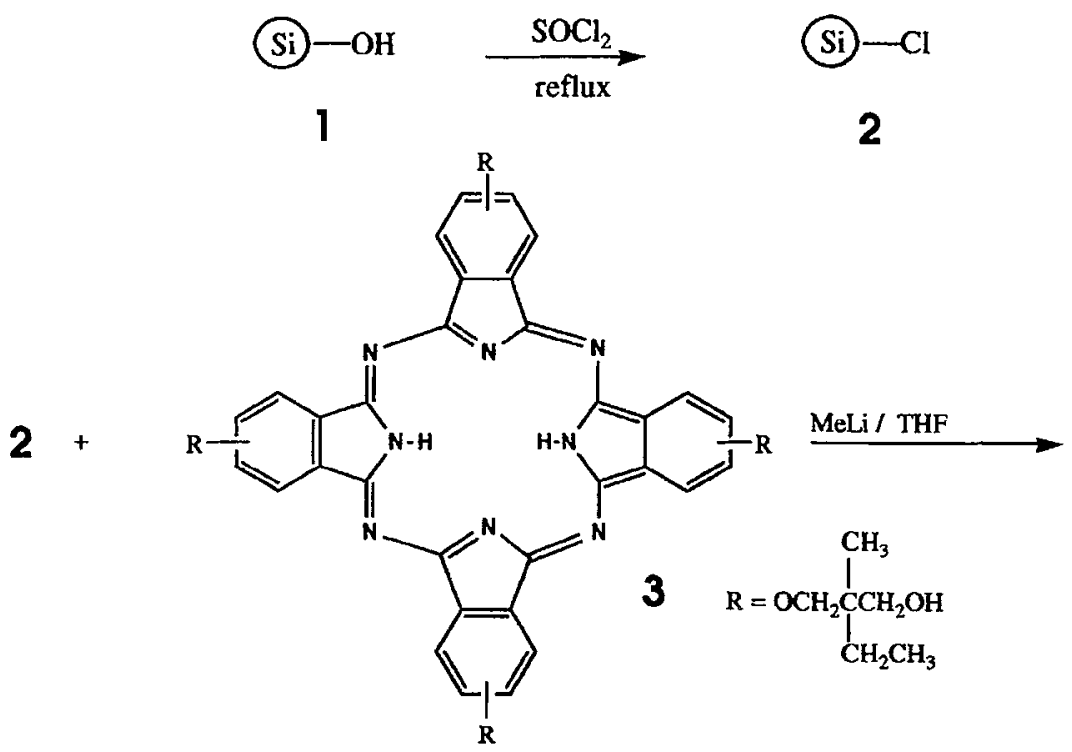

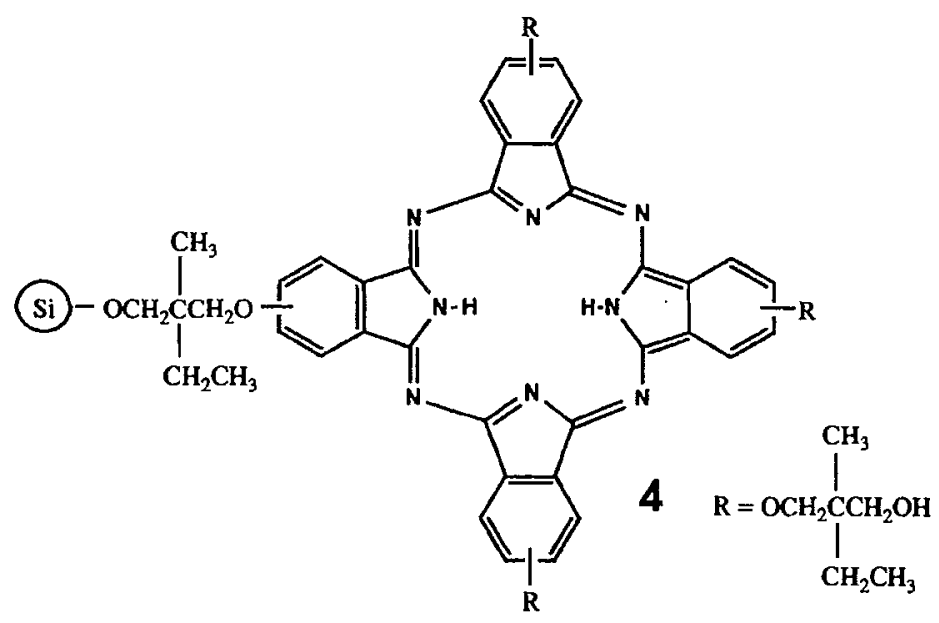

SCHEME 1

In the second group of Pc-Si-Gels, the metal atoms of metallophthalocyanines are bonded with the oxygen atoms of silica gels (Scheme 2). Thus, reactions of 2,9,16,23-tetratert-butylphthalocyanine (5) (27), 2,9,16,23-tetraneopentoxyphthalocyanine (6) (28), or unsubstituted phthalocyanine (7) with trimethyl aluminum and 1 gave 2,9,16,23-tetra-tertbutylphthalocyaninato aluminum(III) silica (8), 2,9,16,23tetraneopentoxyphthalocyaninato aluminum(III) silica (9), or phthalocyaninato aluminum(III) silica (10), respectively.

In the third group, the metal atom of the phthalocyanine is bonded to the nitrogen atom of an aminopropyl derivative of silica (29) (Scheme 3). During the process of preparation, 1 reacted with (3-aminopropyl)trimethoxysilane (11) to give 3-aminopropylsilyl silica (12), which then reacted with methylaluminum(III) phthalocyanine (13) and gave phthalocyaninato aluminum(II) aminopropylsilyl silica (14).

To determine the loadings of immobilized Pc in the Pc-SiGels, three accurately weighed samples of each of the Pc-SiGels were hydrolysed with hydrochloric acid. Comparison of the UV spectra of the filtrates with reference solutions, also under acidic conditions, gave the values of the loadings, which are summarized in Table 1 . In all examples the silica gels recovered from acidic hydrolyses were colourless and indeed hydrolyses were continued until the silica gels were colourless. Three species of the Pc-Si-Gels, namely 4, 9, and 14, were chosen to pack columns. One of the Pc-Si-Gels, 4, was abandoned as it was found to be unstable in the alcoholic solvent (2-methoxyethanol:toluene $=4: 6$ ) used in the column-cleaning process. Among the Pc-Si-Gels 8-10, compound 8 was formed in lower yield while 10 was abandoned in favour of 14, a chain-extended analog of 10, and hence $\mathbf{8}$ and 10 were not examined further.

Four homogeneous mixed condensations were used to prepare mixtures of unsymmetrical phthalocyanines. The mixed condensation of 2,3-dihydro-1,3-diimino- $1 H$-benz $[f]$ isoindole (15) with 5-neopentoxy-1,3-diiminoisoindoline (16) or 5-tert-butyl-1,3-diiminoisoindoline (17) gave mixtures containing 2,9,16-trineopentoxy-31H,33H-tribenzo[b,g,l]naptho[2,3-q]porphyrazine (18) or 2,9,16-tri-tert-butyl$31 H, 33 H$-tribenzo $[b, g, l]$ naphtho $[2,3-q]$ porphyrazine (19) (Scheme 4). The mixed condensation of 16 and 17 gave a mixture containing 2-tert-butyl-9,16,23-trineopentoxyphthalocyanine (20) (Scheme 5). The mixed condensation of 4,5-di-(1-octyn-1-yl)phthalonitrile $(21)^{2}$ and 4-methoxy-

\footnotetext{
${ }^{2} \mathrm{C}$. C. Leznoff and K. Nolan. Unpublished work.
} 


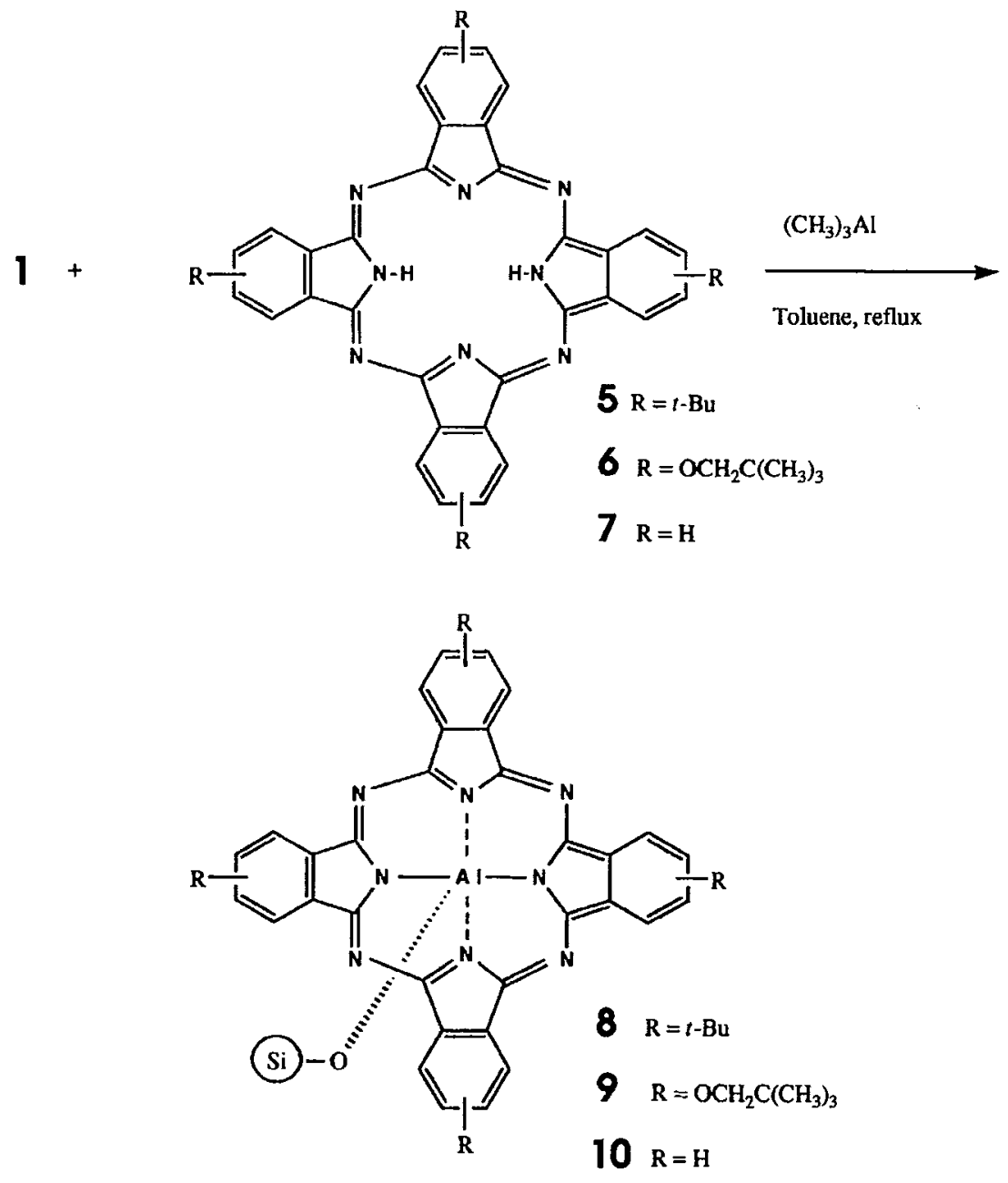

SCHEME 2

methyloxyphthalonitrile (22) (30) with DBU and zinc acetate gave a mixture containing 2,3-di-(1-octyn-1-yl)9,16,26-tri-(methoxymethyloxy)phthalocyanine zinc(II) (23) (Scherne 6).

Among those desired phthalocyanines, 23 was successfully purified by ordinary column chromatography with the help of reverse phase HPLC as a monitor. The other three species, 18, 19, and 20 , could not be completely purified by ordinary column chromatography, but were successfully purified by Pc-Si-Gel column chromatography with the help of reverse phase HPLC or UV as a monitor.

The mass spectra and other data showed that complete separations were achieved. For instance, the mass spectrum of 18 showed that none of the phthalocyanines (porphyrazines) containing di-, tri-, or tetrabenzo groups or tetraneopentoxyphthalocyanines contaminated the desired unsymmetrical phthalocyanine. As a comparison, the same crude products were subjected to ordinary flash chromatography for as many as four repetitive columns. Even so, the mass spectra of the purest fractions showed that substantial contamination by undesired phthalocyanines still occurred (e.g., $m / z$ 858, tetraneopentoxyphthalocyanine; 786, dibenzodineopentoxyphthalocyanine (dibenzodinaphthoporphyrazines)).

It should be noted that each of the unsymmetrical phthal- ocyanines $(\mathbf{1 8}-\mathbf{2 0}, \mathbf{2 3})$ are likely a mixture of several closely related site-isomers. So far, we have not seen any successful example of the separation of such phthalocyanine isomers by chromatographic methods. This method does not readily separate similar isomers such as 2,9,16,23-, $2,10,16,24-, 2,9,17,24$-, and 2,9,16,24-tetraneopentoxyphthalocyanine (6) and this mixture has normally been represented as the $2,9,16,23$ isomer.

The experiments showed that the Pc-Si-Gels have some enhanced ability relative to standard silica gel for the purification of phthalocyanines. The separation ability of Pc-SiGels may depend on a number of complicated factors: amongst others, the nature of the phthalocyanines to be separated, the solvent system employed, and the chemical nature and physical condition of the phthalocyanines bonded to the polymer. Further studies of this new strategy are required before a general statement in this regard can be made. As well, additional work will be aimed at further enhancement of the capabilities of Pc-Si-Gels in practical applications.

\section{Experimental}

High-purity argon was used to maintain inert atmosphere conditions. Infrared (IR) spectra were recorded on a Pye Unicam SP-3200 infrared spectrophotometer using KBr discs for solids or 


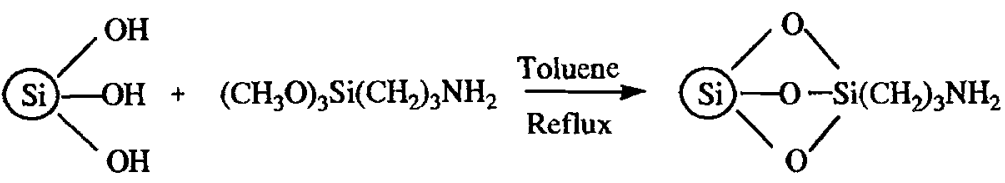

1

11

12

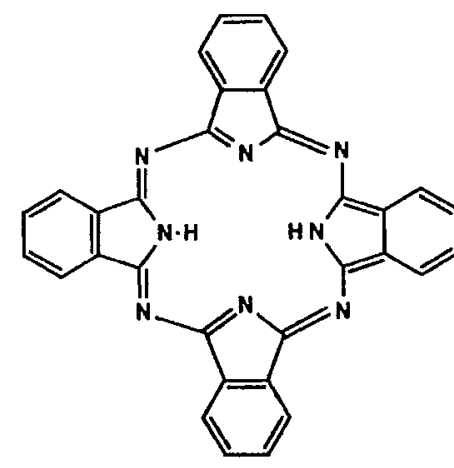

7

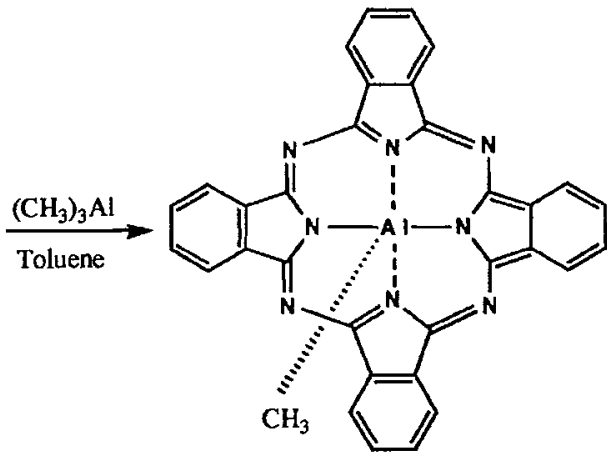

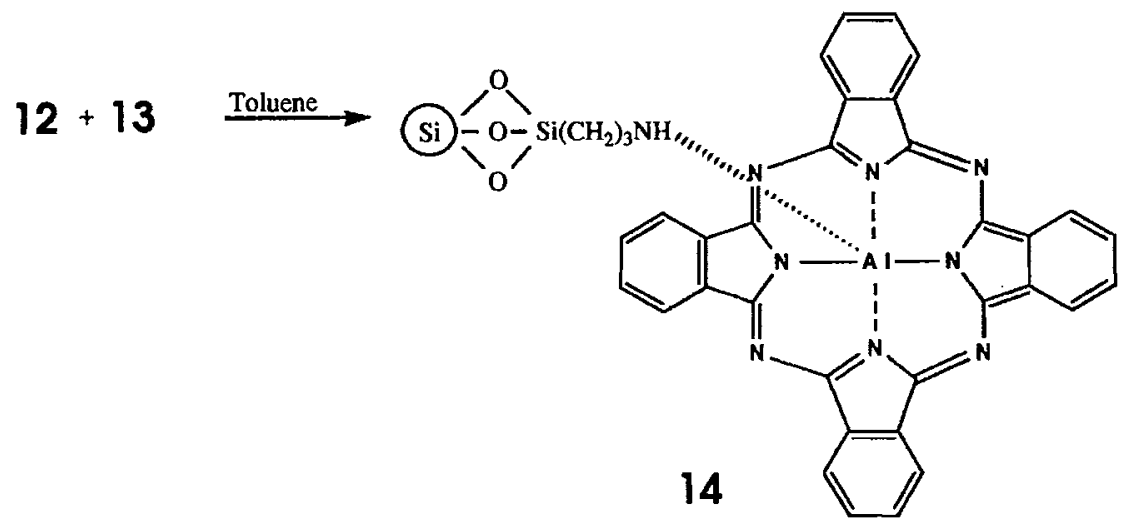

SCHEME 3

TABLE 1. Some properties of Pc-Si-Gels

\begin{tabular}{cccl}
\hline \hline Pc-Si-Gels & Pc loading $(\mathrm{mg} / \mathrm{g})(\mathrm{mmol} / \mathrm{g})$ & Yield $^{a}(\%)$ & \multicolumn{1}{c}{ Colour } \\
\hline $\mathbf{4}$ & $18.7(0.020)$ & 66.5 & Dark green \\
$\mathbf{8}$ & $14.4(0.019)$ & 47.0 & Dark blue \\
$\mathbf{9}$ & $28.7(0.033)$ & $\sim 100$ & Dark green \\
$\mathbf{1 0}$ & $22.3(0.044)$ & 55.6 & Dark blue \\
$\mathbf{1 4}$ & $29.9(0.056)$ & $\sim 100$ & Dark blue-grey \\
\hline
\end{tabular}

${ }^{a}$ Usually, the functional groups on silica gel are used as the limiting reagents, but in these cases, since the functional groups on silica gel were in excess, the yields were calculated using the phthalocyanines as the limiting reagents.

as neat films between $\mathrm{NaCl}$ discs for liquids. Nuclear magnetic resonance (NMR) spectra for carbons and protons were recorded on a Bruker AM300 NMR spectrometer using tetramethylsilane as the internal standard. The positions of the signals are reported in $\delta$ units. The splittings of the signals are described as singlets (s), doublets $(\mathrm{d})$, triplets $(\mathrm{t})$, quartets $(\mathrm{q})$, or multiplets $(\mathrm{m})$. The ${ }^{1} \mathrm{H}$ NMR spectra of $10^{-4} \mathrm{M}$ solutions of the phthalocyanines were obtained by averaging 500-3000 scans over the absorption range. The ${ }^{13} \mathrm{C}$ NMR spectra of $5 \times 10^{-4} \mathrm{M}$ solutions of the phthalocyanines were obtained by averaging 7000-15000 scans. The ultraviolet- visible spectra (UV-VIS) were recorded on a Hewlett Packard HP8451 A diode array spectrophotometer. Mass spectra (MS) were recorded at $70 \mathrm{eV}$ on a VG Micromass $16 \mathrm{~F}$ mass spectrometer in the El mode for relatively small molecules (generally less than $800 \mathrm{amu}$ ). The Fast Atom Bombardment mode (FAB) spectra were obtained with a Kratos Profile or Kratos MS-50 analyzer mass spectrometer equipped with a FAB ion source of standard Kratos design and Ion Tech atom gun for relatively large molecules (generally greater than $800 \mathrm{amu}$ ).

Melting points (mp) were determined using a Kofler hot stage 
<smiles>N=C1NC(=N)c2cc3ccccc3cc21</smiles><smiles>[13CH3]</smiles>

15<smiles>[R]c1ccc2c(c1)C(=N)NC2=N</smiles>

$16 \mathrm{R}=\mathrm{OCH}_{2} \mathrm{C}\left(\mathrm{CH}_{3}\right)_{3}$ $17 \mathrm{R}=\mathrm{C}\left(\mathrm{CH}_{3}\right)_{3}$

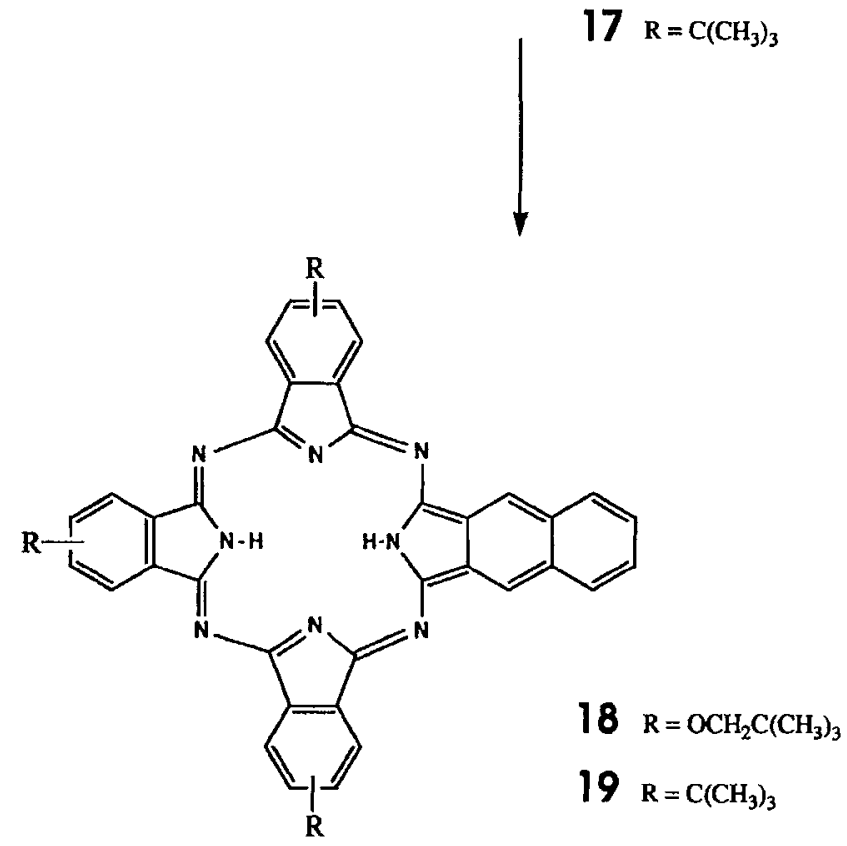

SCHEME 4

melting point apparatus and are uncorrected. Thin-layer chromatography (TLC) was performed using Kodak 13181 silica gel TLC sheets unless otherwise stated. Flash chromatography was performed using silica gel of particle size $20-45 \mu \mathrm{m}$ (purchased from Terochem Laboratories Ltd., equivalent to Merck 9385). Neutral alumina column chromatography was performed using Brockmann I standard grade (150 mesh, $155 \mathrm{~m}^{2} / \mathrm{g}$ ). Reaction mixtures were stirred with a magnetic stirrer, except those that required sonication. Ultrasound treatment was carried out using a Branson 1200 sonicator. Microanalyses were performed by Guelph Chemical Laboratories Ltd., Guelph, Ont. All diiminoisoindolines were used directly without purification, after evaporation of the solvent in condensation experiments. All yields were not optimized by detailed investigation of the effects of temperature, reaction time, and other conditions.

Activated flash silica gel (1)

Flash grade silica gel $(20-45 \mu \mathrm{m}$, purchased from Terochem Laboratories Ltd.) was heated under reflux with concentrated hydrochloric acid for $4 h$. The ratio of concentrated hydrochloric acid to 1 was $4-5 \mathrm{~mL} / \mathrm{g}$. After cooling to room temperature, 1 was filtered, washed with distilled water until the filtrate was neutral, preliminarily dried in an oven, and thoroughly dried under vac$\operatorname{uum}\left(140^{\circ} \mathrm{C}, 0.05\right.$ Torr $(1$ Torr $\left.=133.3 \mathrm{~Pa}), 3 \mathrm{~h}\right)$.

Chlorinated silica gel (2)

Freshly distilled thionyl chloride $(30 \mathrm{~mL})$ was injected into a round-bottom flask that contained $5.7 \mathrm{~g}$ of 1 under argon. After heating under reflux with stirring for $24 \mathrm{~h}$, the mixture was filtered under argon in a Schlenk tube. After washing with dry dichloromethane $(20 \mathrm{~mL}$, three times) by injection, the chlorinated silica gel was obtained as a white powder.

To determine the chlorine loading, three accurately weighed<smiles>CC(C)(C)Oc1ccc2c(c1)C(=N)NC2=N</smiles>

16

17

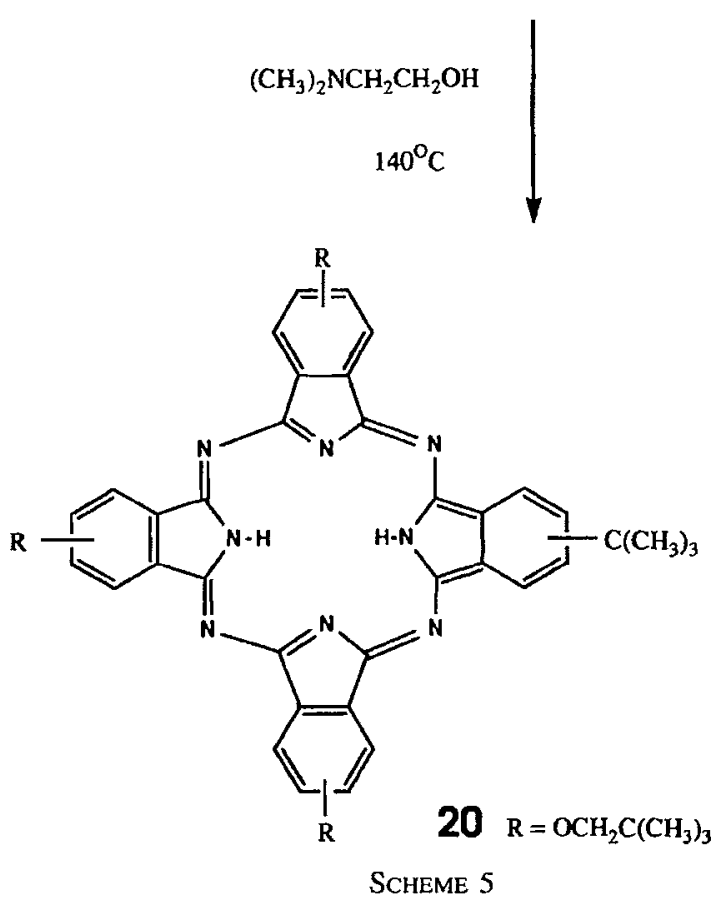

samples of 2 (about $50 \mathrm{mg}$ each) were taken out and immediately treated with $10 \mathrm{~mL}$ of distilled water with stirring. After 10 min, the suspensions were titrated with a $0.1 \mathrm{M}$ aqueous solution of potassium hydroxide and compared with a blank assay. The chlorine loadings were determined to be $\sim 1.0 \pm 0.1 \mathrm{mmol}$ per gram of silica gel. Different batches of silica gel yielded chlorine loadings of $0.8-1.8 \mathrm{mmol} / \mathrm{g}$.

\section{2,9,16,23-Tetrakis(2-hydroxymethyl-2-methylbutoxy)phthalo- cyanine (3) modified silica gel (4)}

A solution of $3(162 \mathrm{mg}, 0.17 \mathrm{mmol})$ (14) in $30 \mathrm{~mL}$ of dry tetrahydrofuran (THF) and $0.5 \mathrm{~mL}$ of $1.4 \mathrm{M}$ methyllithium solution in toluene was injected into a round-bottom flask that contained $5.7 \mathrm{~g}$ of 2 . The mixture was stirred at room temperature for $24 \mathrm{~h}$. After filtering and washing with dry toluene and dry THF (three times each), a dark green powder of Pc-Si-Gel 4 was obtained.

To determine the loading of phthalocyanine on silica gel, three accurately weighed samples of $\mathbf{4}$ (about $50 \mathrm{mg}$ each) were hydrolysed in $10 \mathrm{~mL}$ of hydrochloric acid solution $\left(\mathrm{HCl}: \mathrm{THF}: \mathrm{H}_{2} \mathrm{O}=\right.$ $1: 8: 1$ ) by heating under reflux for $1 \mathrm{~h}$, and then were filtered. Comparison of the UV-VIS spectra of the filtrate with a solution of 3 as a reference showed that the loading of phthalocyanine on 4 was $18.7 \mathrm{mg}$ per gram of silica gel $(0.020 \mathrm{mmol} / \mathrm{g})$. The yield was $66 \%$ with 3 as the limiting reactant.

\section{2,9,16,23-Tetra-tert-butylphthalocyaninatoaluminum(III) silica}

(8)

Trimethylaluminum ( $8.5 \mathrm{~mL}$ of $2 \mathrm{M}$ solution in toluene) was injected into a round-bottom flask that contained $8.5 \mathrm{~g}$ of 1 and $30 \mathrm{~mL}$ of dry toluene under argon. The suspension was stirred at room temperature overnight, then filtered and washed once with 
<smiles>CCC#Cc1cc(C#N)c(C#N)cc1C#CCCC</smiles>

21
$+$<smiles>CCOc1ccc(C#N)c(C#N)c1</smiles>

22
DBU, $\left(\mathrm{CH}_{3} \mathrm{CO}_{2}\right)_{2} \mathrm{Zn}$

$n$-Butanol, reflux

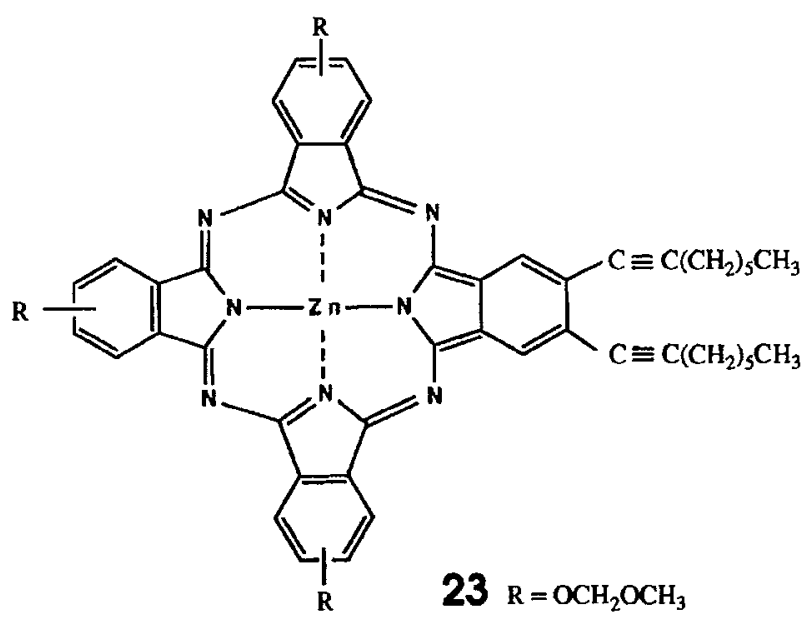

SCHEME 6

dry toluene. A solution of 2,9,16,23-tetra-tert-butylphthalocyanine (5) (27) (260 mg, $0.35 \mathrm{mmol}$ ) in $40 \mathrm{~mL}$ of dry toluene was then injected. The reaction was monitored by removal of an aliquot and examination by UV-VIS spectroscopy to ensure that all of 8 was consumed. The suspension was stirred under reflux for $48 \mathrm{~h}$, at which time the reaction was complete, and then was filtered. The dark blue powder was first washed with dry toluene until the solvent was almost colourless, then washed with dry THF three times, with dry dichloromethane three times, and dried in the air.

Three accurately weighed samples (about $50 \mathrm{mg}$ each) were hydrolysed by heating under reflux for $2 \mathrm{~h}$ with $10 \mathrm{~mL}$ of hydrochloric acid solution ( $\left.\mathrm{HCl}: \mathrm{THF}: \mathrm{H}_{2} \mathrm{O}=1: 8: 1\right)$. After filtration, the comparison of the UV-VIS spectrum of the filtrate with that of a similar acidic reference solution of the starting material 5 showed that the loading of 5 on 8 was $14.4 \mathrm{mg}$ per gram of silica gel $(0.019 \mathrm{mmol} / \mathrm{g})$. The yield was $47 \%$ with 5 as the limiting reactant.

\section{2,9,16,23-Tetraneopentoxyphthalocyaninatoaluminum(III) silica} (9)

Trimethylaluminum $(6.0 \mathrm{~mL}$ of $2 \mathrm{M}$ solution in toluene) was injected under argon into a round-bottom flask that contained $6.0 \mathrm{~g}$ of 1 and $25 \mathrm{~mL}$ of dry toluene. The suspension was stirred at room temperature overnight, then filtered and washed once with dry toluene. A solution of 2,9,16,23-tetraneopentoxyphthalocyanine (6) (28) (168 mg, $0.20 \mathrm{mmol}$ ) in $30 \mathrm{~mL}$ of dry toluene was then injected. The suspension was stirred under reflux for $48 \mathrm{~h}$ until the reaction was complete (as monitored for 8 above) and then was filtered. The filtrate was almost colourless. The dark green powder was then washed with dry toluene three times, with dry THF three times, with dry dichloromethane three times, and dried in the air. Three accurately weighed samples (about $50 \mathrm{mg}$ each) were taken and hydrolysed by heating under reflux for $2 \mathrm{~h}$ with $10 \mathrm{~mL}$ of hydrochloric acid solution ( $\mathrm{HCl}:$ THF: $\mathrm{H}_{2} \mathrm{O}=1: 8: 1$ ). After filtration, comparison of the UV-VIS spectrum of the filtrate with that of a reference solution of the starting material 6 showed that the loading of 6 on 9 was $28.7 \mathrm{mg}$ per gram of silica gel $(0.033 \mathrm{mmol} / \mathrm{g})$. The yield was $100 \%$ with 6 as the limiting reactant.

\section{Phthalocyaninatoaluminum(III) silica (10)}

Unsubstituted phthalocyanine $7(1.28 \mathrm{~g}, 2 \mathrm{mmol})$ was mixed with $50 \mathrm{~mL}$ of a $1.9 \mathrm{M}$ solution of trimethylaluminum in toluene under argon. This mixture was treated with ultrasound for $24 \mathrm{~h}$ to improve solubility and then filtered through a Schlenk tube into a flask containing $24 \mathrm{~g}$ of 1 . After heating under reflux for $48 \mathrm{~h}$ under argon, the mixture was filtered in the Schlenk tube and washed with dry toluene and dry dioxane. The dark blue modified silica gel was then treated with dry dioxane, which allowed the unbound unsubstituted phthalocyanine to be removed by floatation. After the floatation procedure was repeated a few times, no visible unbound phthalocyanine remained and the Pc-Si-Gel 10 was obtained as a dark blue powder.

To determine the loading of 7 on $\mathbf{1 0}$, three accurately weighed samples of 10 (about $50 \mathrm{mg}$ each) were taken and hydrolysed by heating for $2 \mathrm{~h}$ under reflux with $10 \mathrm{~mL}$ of hydrochloric acid solution (HCl:THF: $\mathrm{H}_{2} \mathrm{O}=1: 8: 1$ ). After filtration, comparison of the UV-VIS spectrum of the filtrate with that of an acidic reference sample, which was prepared by hydrolysis of 13 and diluted to a suitable concentration for the UV-VIS spectrum, showed that the loading of 7 on 10 was $22.3 \mathrm{mg}$ per gram of silica gel $(0.044 \mathrm{mmol} / \mathrm{g})$. The yield was $55.6 \%$, with 7 as the limiting reactant.

\section{3-Aminopropylsilyl silica (12)}

Activated dry silica gel $(1,55 \mathrm{~g})$ was mixed with $30 \mathrm{~mL}(160$ mmol) of (3-aminopropyl)trimethoxysilane (11) and $250 \mathrm{~mL}$ of dry toluene. The suspension was stirred under reflux overnight, and then filtered. The solids were washed with dry toluene and anhydrous ether to give 12 .

To determine the amino group loading, three accurately weighed samples (about $50 \mathrm{mg}$ each) were treated with $5 \mathrm{~mL}$ of $0.05 \mathrm{M}$ aqueous solution of sulphuric acid for $10 \mathrm{~min}$, then filtered and titrated with a $0.1 \mathrm{M}$ aqueous solution of potassium hydroxide. Comparison with a blank assay showed that the amino loading on 12 was $0.8-1.3 \mathrm{mmol}$ per gram of silica gel.

\section{Phthalocyaninato methylaluminum(III) (13)}

A mixture of $1.6 \mathrm{~g}(3.1 \mathrm{mmol})$ of metal-free unsubstituted phthalocyanine $7,10 \mathrm{~mL}$ of a $1.9 \mathrm{M}$ solution of trimethylaluminum (19 mmol) in toluene, and $100 \mathrm{~mL}$ of dry toluene was treated with ultrasound for $24 \mathrm{~h}$ to give a solution of phthalocyaninato methylaluminum(III) 13. Without purification and characterization, 13 was used to prepare 14 immediately.

\section{Phthalocyaninatoaluminum(III) aminopropylsilyl silica (14)}

The newly prepared $12(55 \mathrm{~g})$ and $100 \mathrm{~mL}$ of dry toluene were poured with vigorous stirring into a round-bottom flask containing $110 \mathrm{~mL}$ of a hot solution of 13 under argon. After heating under reflux for $1 \mathrm{~h}$, at which time reaction was complete (as monitored for 8 above), the suspension was filtered to give a dark blue-grey powder and an almost colourless filtrate. The powder was then washed with dry toluene three times, followed by dry dioxane three times, to give 14.

To determine the phthalocyanine loading on 14, three accurately weighed samples of 14 (about $50 \mathrm{mg}$ each) were taken and hydrolysed by heating for $1 \mathrm{~h}$ under reflux with $10 \mathrm{~mL}$ of hydrochloric acid solution ( $\left.\mathrm{HCl}: \mathrm{THF}: \mathrm{H}_{2} \mathrm{O}=1: 8: 1\right)$. After filtration, comparison of the UV-VIS spectrum of the filtrate with that of an acidic reference sample, prepared by hydrolysis of 13 and diluted to a suitable concentration for the UV-VIS spectrum, showed that the loading of 7 was $29.0 \mathrm{mg}$ per gram of $14(0.056 \mathrm{mmol} / \mathrm{g})$. The yield was $\sim 100 \%$ with 7 as the limiting reactant. 


\section{2,9,16-Trineopentoxy-3/H,33H-tribenzo/b,g,1]naphtho- $[2,3,-\mathrm{q}]$ porphyrazine (18)}

A solution of 15 derived from $178 \mathrm{mg}$ (1 mmol) of 2,3-dicyanonaphthalene (12) (Tokyo Kasei) and 16 derived from $642 \mathrm{mg}$ (3 mmol) of 4-neopentoxyphthalonitrile (15) (28) in $4 \mathrm{~mL}$ of $2-N, N$ dimethylaminoethanol was heated under reflux for $48 \mathrm{~h}$. The dark green mixture was then poured into $100 \mathrm{~mL}$ of water, and the precipitate was filtered and washed with methanol a few times until the filtrate was colourless. After flash chromatography with toluene as solvent, $356 \mathrm{mg}$ of a phthalocyanine mixture was obtained in about $43.5 \%$ yield. The phthalocyanine mixture was then subjected to common flash silica gel chromatography using carbon tetrachloride/toluene (30/0-70/100) as the eluting solvent, while monitoring with UV-VIS spectroscopy, to afford crude 18. Further purification was effected by column chromatography with 14 or 9 as the static phase. After evaporation of the solvent and precipitation from methanol, the desired 2,9,16-trineopentoxy$31 \mathrm{H}, 33 \mathrm{H}$-tribenzo[ $b, g, l]$ naphtho[2,3-q]porphyrazine (18, 104.5 mg) was obtained, in $12.7 \%$ yield, as a purple solid; $\mathrm{IR}\left(\mathrm{KBr}, \mathrm{cm}^{-1}\right)$ : $3300(\mathrm{w}, \mathrm{NH}), 1620$ (vs, C =C), 1240 (s, COC), 1100 (s, COC), 1020 (vs, NH), 750 (s, $\mathrm{CH}_{\text {arom }}$ ); UV-VIS (1,2-dichlorobenzene, $\mathrm{nm})(\log \epsilon): 734(5.00), 690(4.94), 670(4.70), 622(4.22), 400$ (4.49), 344 (4.72), 300 (4.51); ${ }^{1} \mathrm{H}$ NMR $\left(\mathrm{CDCl}_{3}\right)$ 8: 7.0-9.1 (vbr, aromatic), $4.0-4.2\left(\mathrm{~m},-\mathrm{OCH}_{2} \mathrm{C}-, 6 \mathrm{H}\right), 1.1-1.6\left(\mathrm{~m},-\mathrm{CH}_{3}, 27 \mathrm{H}\right)$, -3.6 (br N-H); ${ }^{13} \mathrm{C}$ NMR (toluene- $\left.d_{8}\right) \delta$ : $116-162\left(C_{\text {arom }}\right), 78$ $\left(\mathrm{CH}_{2}-\mathrm{O}\right), 27.2\left(\mathrm{C}-\mathrm{CH}_{3}\right), 19.7-21.2\left(\mathrm{C}-\mathrm{CH}_{3}\right)$; $\mathrm{MS}(\mathrm{FAB}) \mathrm{m} / \mathrm{z}: 823$ $\left(\mathrm{M}^{+}+1100 \%\right), 752(19 \%), 681(9 \%)$. Anal. calcd. for $\mathrm{C}_{51} \mathrm{H}_{50} \mathrm{~N}_{8} \mathrm{O}_{3}$ : C 74.42, H 6.12, N 13.61; found: C 73.84, H 6.32, $\mathrm{N} 13.26$.

The mass spectrum of 18 showed no contamination by undesired phthalocyanines. As a comparison, the same crude product was subjected four times to ordinary flash silica gel chromatography. The mass spectrum of its purest components indicated that it still contained some 2,9,16,23-tetraneopentoxyphthalocyanine.

\section{2,9,16-Tri-tert-butyl-3/H,33H-tribenzo[b,g,1]naphtho- \\ [2,3-q]porphyazine (19)}

A solution of 15 derived from $178 \mathrm{mg}(1 \mathrm{mmol})$ of 2,3-dicyanonaphthalene (Tokyo Kasei) and 17 derived from $552 \mathrm{mg}$ ( $3 \mathrm{mmol}$ ) of 4-tert-butylphthalonitrile (27) (Toyko Kasei) in $4 \mathrm{~mL}$ of 2-N,N-dimethylaminoethanol was heated under reflux for $48 \mathrm{~h}$. The dark blue mixture was then poured into $100 \mathrm{~mL}$ of water to form a precipitate. The precipitate was filtered and washed with methanol a few times until the filtrate was colourless. After column chromatography with ordinary flash silica gel as the static phase and toluene as the eluting solvent, $198 \mathrm{mg}$ of a phthalocyanine mixture was obtained in about $27 \%$ yield. The phthalocyanine mixture was then separated again by flash silica gel chromatography to get the crude 19 . Further purification was effected by column chromatography with Pc-Si-Gel 14 or 9 as the static phase, with carbon tetrachloride/toluene $(70 / 30-0 / 100)$ as the eluting solvent and using UV-VIS spectroscopy as a monitor. After evaporation of the solvent and precipitation from methanol, $52.8 \mathrm{mg}$ of pure 2,9,16-tri-tert-butyl-31 $\mathrm{H}, 33 \mathrm{H}$-tribenzo$[b, g, l]$ naphtho[2,3-q]porphyazine (19) was obtained, in $7.2 \%$ yield, as a purple solid, $\mathrm{IR}\left(\mathrm{KBr}, \mathrm{cm}^{-1}\right): 3300(\mathrm{w}, \mathrm{NH}), 1620(\mathrm{vs}, \mathrm{C}=\mathrm{C})$, 1010 (vs, $\mathrm{NH}$ ), 750 (s, $\mathrm{CH}_{\text {arom }}$ ); UV-VIS (1,2-dichlorobenzene, nm) (log $\epsilon): 730(5.10), 686(5.09), 666(4.82), 618(4.47), 346$ (4.85), 302 (4.52); ${ }^{\mathrm{i}} \mathrm{H} \mathrm{nmr}$ (toluene- $d_{8}$ ) $8: 6.9-8.1,8.6-9.5$ (vbr, aromatic), $1.7-1.8\left(\mathrm{~m},-\mathrm{CH}_{3}, 27 \mathrm{H}\right),-2.3($ br $\mathrm{N}-H) ;{ }^{13} \mathrm{C} \mathrm{nmr}$ (toluene- $\left.d_{8}\right) \delta: 122.5-152.8\left(C_{\text {arom }}\right), 35.8-36.0\left(C-\mathrm{CH}_{3}\right), 32.1-32.3$ $\left(\mathrm{C}-\mathrm{CH}_{3}\right)$; $\mathrm{MS} m / 2: 733\left(\mathrm{M}^{+}+1,100 \%\right), 718(22 \%), 703(9 \%), 676$ (17\%). Anal. calcd. for $\mathrm{C}_{48} \mathrm{H}_{44} \mathrm{~N}_{8}$ : C 78.66, H 6.05, N 15.29; found: C $78.19, \mathrm{H} 6.25, \mathrm{~N} 15.14$.

The mass spectrum of 19 showed no contamination by undesired phthalocyanines. As a comparison, an attempt was made to purify the same crude 19 by a series of four ordinary flash chromatographic operations. The mass spectrum of its purest part showed that it still contained some 2,9,16,23-tetra-tert-butylphthalocyanine.
2-tert-Butyl-9,16,23-trineopentoxyphthalocyanine (20)

A solution of 16 derived from $107 \mathrm{mg}(0.5 \mathrm{mmol})$ of 4-neopentoxyphthalonitrile (28) and 17 derived from $276 \mathrm{mg}$ ( $1.5 \mathrm{mmol}$ ) of 4-tert-butylphthalonitrile (27) in $2 \mathrm{~mL}$ of $2-N, N$-dimethylaminoethanol was heated under reflux for $48 \mathrm{~h}$. The dark blue mixture was then poured into $50 \mathrm{~mL}$ of distilled water to form a precipitate. The precipitate was filtered and washed with methanol for a few times until the filtrate was colourless. After column chromatography with flash silica gel as the static phase and toluene as the eluting solvent, $115 \mathrm{mg}$ of a phthalocyanine mixture was obtained, in about $28 \%$ yield, as a purple solid. The phthalocyanine mixture was then subjected to both ordinary flash chromatography and chromatography using Pc-Si-Gels 9 or 14 with carbon tetrachloride/toluene $(70 / 30-0 / 100)$ as the eluting solvent. Reverse phase HPLC was used as the monitor to check the purity of the eluted fractions. After six repetitive chromatographic separations and precipitation from methanol, $10.5 \mathrm{mg}$ of the desired 2-tert-butyl-9,16,23-trineopentoxyphthalocyanine (20) was obtained, in $2.5 \%$ yield, as a purple solid; IR $\left(\mathrm{KBr}, \mathrm{cm}^{-1}\right): 3300$ $(\mathrm{w}, \mathrm{NH}), 1620$ (vs, C=C), 1240 (s, COC), 1100 (s, COC), 1020 (vs, NH); 750 (s, CH rrom); UV-VIS (1,2-dichlorobenzene, nm) (log e): $708(5.20), 674(5.11), 640(4.66), 607(4.47), 348(4.85) ;{ }^{1} \mathrm{H}$ $\mathrm{nmr}\left(\mathrm{CDCl}_{3}\right)$ 8: 7.3-9.7 (vbr, aromatic), 4.1-4.6 (m, $-\mathrm{OCH}_{2} \mathrm{C}$ $6 \mathrm{H}), 1.1-1.6\left(\mathrm{~m},-\mathrm{CH}_{3}, 36 \mathrm{H}\right),-3.5(\mathrm{br} \mathrm{N}-\mathrm{H}) ;{ }^{13} \mathrm{C} \mathrm{nmr}$ (toluene$\left.d_{8}\right) \delta: 118-160\left(C_{\text {arom }}\right), 78\left(C_{2}-\mathrm{O}\right), 27.2\left(C-\mathrm{CH}_{3}\right), 19.7-21.2$ (C- $\left.\mathrm{CH}_{3}\right)$; MS (FAB) $m / z: 829\left(\mathrm{M}^{+}+1,100 \%\right), 759$ (20\%). Anal. calcd. for $\mathrm{C}_{51} \mathrm{H}_{56} \mathrm{~N}_{6} \mathrm{O}_{3}:$ C 73.89, H 6.81, N 13.52; found: $\mathrm{C} 73.98$, H 6.84, N 13.12.

\section{2,3-Di-(I-Octyn-1-yl)-9,16,23-trimethoxymethyloxyphthalo- cyaninato zinc(II) (23)}

A mixture of 21 (425 mg, $1.24 \mathrm{mmol}$ ) (19), 22 (467 mg, 2.48 $\mathrm{mmol}$ ) (19), DBU (2 mL), and 1-butanol (4 mL) was heated under reflux with stirring in an argon atmosphere. After 5-10 min, $184 \mathrm{mg}(1.0 \mathrm{mmol})$ of dry zinc acetate was added. After heating for $4-5 \mathrm{~h}$, the dark green-blue mixture was poured into $400 \mathrm{~mL}$ of water, and then extracted three times with toluene. The organic phase was washed with water until it was neutral, then dried with magnesium sulphate. After filtration and evaporation, the crude product underwent a preliminary silica flash column chromatography with toluene/ethyl acetate $(50 / 50-0 / 100)$ as the eluting solvent. A mixture of phthalocyanines $(320 \mathrm{mg})$ was obtained in about $40 \%$ yield, and reverse phase HPLC showed it contained about $40 \%$ of the desired phthalocyanine 23. After three more separations by flash column chromatography with toluene/ethyl acetate $(92 / 8-86 / 14)$ as the eluting solvent, $100 \mathrm{mg}$ of the desired 2,3-dioctynyl-9,16,23-trimethoxymethyloxyphthalocyaninato zinc(II) (23) was obtained, as a purple solid, in $12.4 \%$ yield with 22 as the limiting reactant; IR $\left(\mathrm{KBr}, \mathrm{cm}^{-1}\right.$ ): 1620 (vs, $\mathrm{C}=\mathrm{C}$ ), $1240(\mathrm{~s}, \mathrm{COC}), 1100(\mathrm{~s}, \mathrm{COC}), 750\left(\mathrm{~s}, \mathrm{CH}_{\mathrm{arom}}\right)$; UV-VIS $(1,2-$ dichlorobenzene, $\mathrm{nm})(\log \epsilon): 698$ (5.12), $682(5.02), 624(4.39)$, 357 (4.80); ${ }^{1} \mathrm{H}$ nmr (Benzene- $\mathrm{d}_{6}$ ) $\delta$ : 6.94-8.81 (vbr, aromatic, $11 \mathrm{H}), 4.73-5.02\left(\mathrm{~m},-\mathrm{O}-\mathrm{CH}_{2}-\mathrm{O}, 6 \mathrm{H}\right), 2.97-3.16\left(\mathrm{~m}, \mathrm{CH}_{3}-\mathrm{O}, 9 \mathrm{H}\right)$, $2.57-2.70\left(\mathrm{~m}, \mathrm{C} \equiv \mathrm{C}-\mathrm{CH}_{2}-4 \mathrm{H}\right), 1.07-1.87\left(\mathrm{~m},-\mathrm{C}-\mathrm{CH}_{2}-\mathrm{C}-, 16\right.$ $\mathrm{H}), 0.54-0.64$ (tri, $\left.\mathrm{CH}_{2}-\mathrm{CH}_{3}, 6 \mathrm{H}\right)$; MS (FAB) $\mathrm{m} / \mathrm{z}: 972\left(\mathrm{M}^{+}\right.$, $100 \%), 928(85 \%), 888(50 \%)$. Anal. calcd. for $\mathrm{C}_{54} \mathrm{H}_{52} \mathrm{~N}_{8} \mathrm{O}_{8} \mathrm{Zn}: \mathrm{C}^{2}$ $66.56, \mathrm{H} 5.38, \mathrm{~N} 11.50, \mathrm{Zn} 6.71$; found: C 65.81 , H 5.14, N $11.12, \mathrm{Zn} 6.64$.

\section{Acknowledgements}

We are grateful to the Natural Sciences and Engineering Research Council of Canada for financial support of this research.

1. I. Rosenthal and E. Ben-Hur. In Phthalocyanines: properties and applications. Vol. 1. Edited by C.C. Leznoff and A.B.P. Lever. VCH, New York. 1989. p. 393

2. J.E. van Lier. In Biology and medicine. Vol. 1. Edited by R.H. 
Douglas, J. Moan, and F. Dall'Acqua. Plenum Press, New York. 1988. p. 435.

3. B. Paquette, H. Ali, R. Langlois, and J.E. van Lier. Photochem. Photobiol. 51, 313 (1990).

4. D. Wöhrle, N. Iskander, G. Graschew, H. Sinn, E.A. Friedrich, W. Maier-Borst, J. Stern, and P. Schlag. Photochem. Photobiol. 51, 351 (1990).

5. C.C. Leznoff, S. Vigh, P.I. Svirskaya, S. Greenberg, D.M. Drew, E. Ben-Hur, and I. Rosenthal. Photochem. Photobiol. 49, 279 (1989).

6. I. Rosenthal, E. Ben-Hur, S. Greenberg, A. Concepcion-Lam, D.M. Drew, and C.C. Leznoff. Photochem. Photobiol. 46, 959 (1987).

7. J.D. Spikes. Photochem. Photobiol. 43, 691 (1986).

8. E. Ben-Hur. In From photophysics to photobiology. Edited by A. Favre, R. Tyrrell, and J. Cadet. Elsevier, New York. 1987. p. 407.

9. J.E. van Lier and J.D. Spikes. In Photosensitizing compounds: their chemistry, biology and clinical use. Edited by T.J. Dougherty, G.H. Bock, and S. Harnett. Ciba Found. Symp. 146, 17 (1987).

10. C.C. Leznoff. In Phthalocyanines: properties and applications. Vol. 1. Edited by C.C. Leznoff and A.B.P. Lever. VCH, New York. 1989. p. 1.

11. N. Kobayashi, R. Kondo, S. Nakajima, and T. Osa. J. Am. Chem. Soc. 112, 9640 (1990).

12. Y. Ikeda, H. Konami, M. Hatano, and K. Mochizuki. Chem. Lett. 763 (1992).

13. H. Konami and M. Hatano. Chem. Lett. 1359 (1988).

14. C.C. Leznoff, P.I. Svirskaya, B. Khouw, R.L. Cerny, P. Seymour, and A.B.P. Lever. J. Org. Chem. 56, 82 (1991).
15. C.C. Leznoff, S. Greenberg, B. Khouw, and A.B.P. Lever. Can. J. Chem. 65, 1705 (1987).

16. D. Wöhrle and G. Krawczyk. Polym. Bull. 15, 193 (1986).

17. C. Piechocki and J. Simon. J. Chem. Soc. Chem. Commun. 259 (1985).

18. H. Shirai, K. Hanabusa, M. Kitamura, and E. Masuda. Makromol. Chem. 185, 2537 (1984).

19. C.C. Leznoff and T.W. Hall. Tetrahedron Lett. 23, 3023 (1982).

20. T.W. Hall, S. Greenberg, C.R. McArthur, B. Khouw, and C.C. Leznoff. Nouv. J. Chim. 6, 653 (1982).

21. M.J. Cook, M.F. Daniel, K.J. Harrison, N.B. McKeown, and A.J. Thomson. J. Chem. Soc. Chem. Commun. 1148 (1987).

22. W.A. Nevin, W. Liu, S. Greenberg, M.R. Hempstead, S.M. Marcuccio, M. Melnik, C.C. Leznoff, and A.B.P. Lever. Inorg. Chem. 26, 891 (1987).

23. A. Giraudeau, A. Lovati, M. Gross, J.J. Andre, J. Simon, C.H. Su, and K.M.J. Kadish. J. Am. Chem. Soc. 105, 2917 (1983).

24. M. Abkowitz and A.R.J. Monahan. J. Phys. Chem. 58, 2281 (1973).

25. M.P. McDaniel. J. Phys. Chem. 85, 532 (1981).

26. T. Buck, D. Wöhrle, G. Schulz-Ekloff, and A. Andreev. J. Mol. Catal. 70, 259 (1991).

27. M. Hanack, J. Metz, and G. Pawlowski. Chem. Ber. 115, $2836(1982)$.

28. C.C. Leznoff, S.M. Marcuccio, S. Greenberg, A.B.P. Lever, and K.B. Tomer. Can. J. Chem. 63, 623 (1985)

29. E. Angeletti, C. Canepa, G. Martinetti, and P. Venturello. J. Chem. Soc. Perkin Trans. 1, 105 (1989).

30. Y. Qin. M. Sc. Thesis, York University, Toronto. 1991. pp. 67-68. 